\title{
PENGARUH CORPORATE GOVERNANCE TERHADAP MANAJEMEN PAJAK
}

\author{
Lilianita Hariono Ningrum \\ Fakultas Ekonomi dan Bisnis, Universitas Wijaya Kusuma Surabaya \\ E-mail: lilianitaningrum@gmail.com \\ Erna Hendrawati \\ E-mail : hendrawati@uwks.ac.id \\ Fakultas Ekonomi dan Bisnis, Universitas Wijaya Kusuma Surabaya
}

\begin{abstract}
This research aimed to explain about an influence of corporate governance to tax management. Tax management was measured by effective tax rate, whereas corporate governance was shown by variable, such as size of commissioner, percentage of independent commissioner, institutional ownership, managerial ownership, and audit committee. A sample of this study consists of companies which are listed in wholesale trade sector, retail trade sector, tourism, restaurant, and hotel sector during the year 2014 to 2016. Determination of the sample chosen from purposive sampling method and accomplished a sample of 33 companies based on certain criteria. The data are collected from Indonesia Stock Exchange and used Eviews 8 to analyse multiple regression. The result showed that size of commissioner, percentage of independent commissioner, managerial ownership has influence on tax management. Based on this research, institutional ownership and audit committee has no influence on tax management.
\end{abstract}

Keywords: corporate governance, tax management, effective tax rate

\section{PENDAHULUAN}

Pajak sebagai sumber penerimaan bagi negara merupakan iuran wajib yang dibayar oleh setiap warga negara sebagai orang pribadi atau badan dengan mengacu kepada peraturan perpajakan dan bertujuan memenuhi keperluan negara untuk kesejahteraan rakyat. Indonesia yang memiliki sekitar 250 juta penduduk dan jumlah perusahaan yang semakin besar dapat menjadi kontributor bagi penerimaan pajak negara. Pertumbuhan jumlah perusahaan yang semakin tinggi dapat menjadikan perekonomian negara bergerak cepat dan meningkatkan kesejahteraan masyarakat di sekitar perusahaan. Penghasilan dari kegiatan dalam perusahaan tersebut harus disetorkan sebagai pajak penghasilan sebagai pendapatan untuk mendukung pembangunan nasional.

Pasal 2 Undang-Undang Nomor 36 Tahun 2008 seperti dikutip Halim, Icuk, dan Amin (2014), perusahaan merupakan satu diantara subjek penghasilan, yaitu subjek pajak badan. Perusahaan memiliki tujuan untuk meningkatkan kinerja sehingga nilai perusahaan meningkat (Sudana, 2009). Menurut teori agensi, manajemen sebagai principal memiliki tugas dan tanggung jawab untuk mencapai tujuan tersebut dengan memanfaatkan sumber daya perusahaan secara efisien agar kekayaan pemegang saham menjadi maksimal. Satu diantara strategi yang dapat dilakukan oleh perusahaan adalah dengan efisiensi pembayaran pajak yang diwujudkan melalui manajemen pajak (Putra Irawan, 2012).

Manajemen pajak harus dilakukan dengan baik agar tidak menjurus kepada pelanggaran norma perpajakan (Agustania, 2016), perlunya penerapkan corporate governance agar tercipta sistem pengawasan dan pengendalian, sehingga penyalahgunaan sumber daya perusahaan dapat dicegah, agar kegiatan perusahaan berjalan sesuai dengan harapan pemangku kepentingan (stakeholders). Tujuan perusahaan melakukan Corporate governance adalah tercipta tata kelola perusahaan yang baik, efektif, serta efisien tanpa melanggar aturan yang ditetapkan pemerintah. Menurut Bernad (2011) dalam Meilinda (2013), karakteristik corporate governance sebuah perusahaan dapat menunjukkan bagaimana perusahaan tersebut menerapkan manajemen pajak. Karakteristik tersebut dapat dijalankan oleh dewan komisaris, dewan komisaris independen, investor institusional, direksi, dan komite audit.

Posisi dewan komisaris sebagai wakil atas pemegang saham harus melaksanakan kewajiban untuk mengutamakan kepentingan pemegang saham, yaitu dengan memaksimalkan kekayaan perusahaan yang nilainya dipengaruhi oleh pajak (Sabli dan Noor, 2012 dalam Meilinda, 2013) Tujuan tersebut diwujudkan dengan memberikan 
arahan mengenai kebijakan yang dibuat dalam perusahaan, serta dalam prosesnya yang juga perlu pengawasan oleh dewan komisaris independen. Dewan komisaris independen adalah pihak yang memililki tugas untuk menyeimbangkan dan memisahkan kepentingan dan keinginan antara pemegang saham dengan manajemen perusahaan, serta menjaga perusahaan agar dalam setiap kegiatannya tidak melanggar ketentuan yang ditetapkan (Wulandari dan Septiari, 2015). Adanya kebijakan dari manajemen perusahaan serta pengawasan oleh komisaris independen akan menentukan langkah apa yang harus diambil dalam menjalankan kegiatan dalam perusahaan, termasuk mengenai pembayaran pajak.

Adapun kepemilikan institusional sebagai bentuk kepemilikan saham dalam perusahaan atau lembaga lain dapat menghindarkan manajemen dari sikap oportunistik dan mengurangi tindakan penyelewengan yang dilakukan oleh manajemen, dengan tingkat kepemilikan institusional besar, maka tingkat pengawasan akan semakin tinggi. Bentuk struktur kepemilikan lain seperti kepemilikan manajerial juga dinilai dapat meningkatkan kinerja manajemen. Kepemilikan manajerial merupakan saham yang dimiliki oleh pihak manajemen perusahaan. Kepemilikan manajerial dapat memotivasi manajemen untuk meningkatkan kinerja serta berusaha sebaik mungkin memenuhi keinginan dari para pemegang saham lain.

Pengawasan terhadap kinerja manajemen terkait dengan manajemen pajak juga dapat dilaksanakan oleh komite audit dalam perusahaan. Komite audit adalah komite yang dibentuk oleh dewan komisaris, yang angggotanya diangkat dan diberhentikan oleh dewan komisaris, dan bertugas untuk membantu melakukan pemeriksaan atau penelitian yang dianggap perlu terhadap fungsi direksi dalam pengelolaan perusahaan (Winata, 2014). Fungsi komite audit yang berjalan dengan efektif diharapkan dapat meminimalisasi konflik agensi karena benturan kepentingan, dimana manajemen ingin meningkatkan kesejahterannya sendiri.

Penerapan corporate governance diharapkan menghasilkan kinerja yang baik dan efisien, contohnya melalui laba. Laba yang diperoleh tidak lepas dari pengambilan keputusan serta pemilihan metode akuntansi berkaitan dengan tarif pajak efektif, sehingga perusahaan akan dapat mencapai laba dan likuiditas yang seharusnya dengan cara yang benar karena fungsi dari corporate governance sendiri adalah sebagai pengawas.
Penelitian ini mengulang penelitian dari Wulandari dan Septiari (2015) yang bertujuan untuk mengkaji pengaruh corporrate governance ke manajemen pajak yang bertolok ukur pada tarif pajak efektif.

\section{TINJAUAN PUSTAKA \\ Teori Keagenan (Agency Theory)}

Teori keagenan merupakan hal yang mendasari munculnya konsep serta penerapan corporate governance. Teori agensi menjelaskan adanya hubungan kontrak antara principal sebagai pemilik perusahaan dengan agent, yaitu manajer perusahaan sebagai pihak yang diperkerjakan oleh principal dalam menjalankan kegiatan dalam perusahaan, termasuk dalam setiap tindakan dan pengambilan keputusan, agar terus memprioritaskan kepentingan principal (Jensen dan Meckling, 1976 dalam Wulandari dan Septiari, 2015). Teori keagenan menjelaskan bahwa terdapat konflik yang akan timbul antara pemilik perusahaan dengan manajemen perusahaan.

Konflik tersebut terjadi ketika pemilik perusahaan mengharapkan keuntungan meksimal dari modal yang ditanamkan, sementara di sisi lain terdapat pihak manajemen perusahaan sebagai pengelola perusahaan yang dapat mengambil keputusan terkait manajemen pajak yang mempengaruhi besarnya pajak yang akan disetor ke kas negara. Pihak manajemen akan melakukan manajemen pajak dengan sebaik mungkin agar memperoleh manfaat dalam pembayaran pajak yang lebih rendah ke negara dan menghasilkan laba yang lebih tinggi. Adanya sudut pandang yang berbeda tersebut dapat memicu konflik.

\section{Pajak}

Dalam Undang-Undang No. 16 Tahun 2009 tentang Ketentuan Umum dan Tata Cara Perpajakan, "Pajak adalah kontribusi wajib kepada negara yang terutang oleh orang pribadi atau badan yang bersifat memaksa berdasarkan undangundang, dengan tidak mendapatkan imbalan secara langsung dan digunakan untuk keperluan negara bagi sebesar-besarnya kemakmuran rakyat". Djajadiningrat (2010) seperti yang dikutip oleh Halim, Icuk, dan Amin (2014) menjelaskan pajak sebagai kekayaan pribadi yang wajib diserahkan ke kas negara karena keadaan, kejadian, dan perbuatan yang memberikan kedudukan tertentu, namun bukan merupakan hukuman, dipungut berdasarkan peraturan pemerintah dan dapat dipaksakan, tetapi tidak adanya jasa timbal balik secara langsung dari negara, serta digunakan untuk memelihara negara secara umum. 


\section{Effective Tax Rate}

Effective tax rate (selanjutnya disebut ETR) atau tarif pajak efektif didefiniskan presentase besaran tarif pajak yang ditanggung oleh perusahaan dan dihitung berdasarkan informasi keuangan perusahaan, ETR merupakan bentuk perhitungan tarif pajak pada perusahaan (Aunalal, 2011 dalam Ardyansah, 2014). ETR adalah perbandingan antara pajak riil yang dibayar dengan laba komersial sebelum pajak (Rachmitasari, 2015).

\section{Manajemen Pajak}

Pohan (2013) berpendapat bahwa manajemen pajak adalah segenap upaya untuk mengimplementasikan fungsi-fungsi manajemen yang meliputi perencanaan, pengorganisasian, pelaksanaan, dan pengendalian agar pelaksanaan kewajiban dan hak perpajakan dapat berjalan secara efektif dan efisien sehingga memberi kontribusi maksimum bagi perusahaan. Menurut Sudirjo (2017), manajemen pajak mempunyai tujuan yaitu untuk menerapkan peraturan perpajakan dengan benar, sebagai usaha efisiensi untuk mencapai laba dan likuiditas yang seharusnya, pembayaran pajak menurut hukum dan peraturan yang berlaku, dan menghindari hal-hal yang tidak terduga. Tujuan tersebut dapat diraih melalui fungsi manajemen pajak yang terdiri dari perencanaan pajak (tax planning), pelaksanaan perpajakan (tax implementation), dan pengendalian pajak (tax control).

Tax planning merupakan bagian dari manajemen pajak sekaligus langkah awal yang harus ditempuh dalam melakukan manajemen pajak. Pohan (2013) mendefinisikan tax planning sebagai strategi untuk mengatur akuntansi dan keuangan agar kewajiban perpajakan dapat diminimalkan dengan cara yang tidak melanggar peraturan perpajakan, dengan menggunakan strategi seperti tax avoidance dan tax saving.

Tax avoidance (penghindaran pajak) adalah upaya penghindaran pajak yang dilakukan dengan cara memanfaatkan kelemahan (grey area) dalam peraturan perpajakan itu sendiri, sedangkan tax saving (penghematan pajak) adalah upaya wajib pajak mengelak utang pajaknya dengan jalan menahan diri untuk tidak membeli produk-produk yang ada pajak pertambahan nilainya, atau dengan sengaja mengurangi jam kerja atau pekerjaan yang dapat dilakukannya. Tax saving adalah usaha memperkecil jumlah pajak yang tidak termasuk dalam ruang lingkup perpajakan (Pohan, 2013).

\section{Pengukuran Manajemen Pajak}

Menurut Putra Irawan (2012), berdasarkan penelitian sebelumnya (Dyreng et al., 2008; Minnick dan Noga, 2010; Sari, 2010), perhitungan tarif pajak efektif dapat dibagi dalam dua jenis perhitungan, yaitu melalui GAAP Effective Tax Rate (GETR) dan cash Effective Tax Rate (CETR). ETR merupakan bentuk perhitungan tarif pajak pada perusahaan yang diperoleh berdasarkan informasi keuangan perusahaan. ETR menunjukkan efektivitas manajemen pajak serta menunjukkan respon dan dampak insentif pajak pada suatu perusahaan. Nilai GETR didapatkan dengan membagi total beban pajak penghasilan (tax expense) dengan laba sebelum pajak (pretax income). Pengukuran GETR untuk melihat perbandingan tetap antara laba akuntansi dan laba fiskal. CETR didapatkan dengan membagi total pajak yang dibayar perusahaan (cash taxes paid) dengan laba sebelum pajak. Pengukuran CETR digunakan untuk mengidentifikasi efisiensi pajak yang dibayarkan secara kas.

\section{Corporate Governance}

Forum for Corporate Governance in Indonesia seperti dikutip Wulandari dan Septiari (2015) mendefinisikan corporate governance sebagai seperangkat peraturan yang mengatur hubungan antara pemegang saham, pengelola perusahaan, pihak kreditur, pemerintah, karyawan, serta para pemegang kepentingan internal dan eksternal lainnya, yang berkaitan dengan hak-hak dan kewajiban perusahaan, atau dengan kata lain suatu sistem yang mengendalikan tata kelola perusahaan. Corporate governance sebagai suatu sistem terdiri dari berbagai perangkat serta aturan main (code of conduct) dan hukum yang dibutuhkan untuk menjaga keseimbangan (check and balance) agar sistem dapat bekerja secara optimal, sementara CG sebagai mekanisme adalah tujuan untuk melakukan sesuatu dengan benar, sehingga dalam penerapannya harus memerhatikan cara yang benar sebelum melakukan sesuatu yang dianggap benar (Lukviarman, 2006). Berdasarkan definisi yang telah disebutkan, corporate governance penting bagi kinerja, nilai, serta kredibilitas perusahaan, sehingga penerapan corporate governance merupakan hal yang berarti untuk meraih tujuan dan memilih strategi yang benar untuk perusahaan (Crowther dan Seifi, 2011). 


\section{Prinsip Corporate Governance}

Corporate governance dapat dikatakan baik (good corporate governance) apabila telah memenuhi prinsip-prinsip dasar yang meliputinya (Nazaruddin, 2008). Prinsip corporate governance bedasarkan Pedoman Umum Good Corporate Governance yang dikeluarkan oleh Komite Nasional Kebijakan Governance adalah sebagai berikut:

1. Transparansi (Transparency)

Perusahaan harus menyediakan informasi yang material dan relevan dengan cara yang mudah diakses dan dipahami oleh pemangku kepentingan. Yang diungkap perusahaan tidak hanya masalah yang disyaratkan oleh peraturan perundang-undangan, tetapi juga hal yang penting untuk pengambilan keputusan oleh pemegang saham, kreditur dan pemangku kepentingan lainnya.

2. Akuntabilitas (Accountability)

Perusahaan mempunyai kewajibanan mempertanggungjawabkan kinerjanya secara transparan dan wajar, untuk itu perusahaan harus dikelola secara benar, terukur dan sesuai dengan kepentingan perusahaan dengan tetap memperhitungkan kepentingan pemegang saham dan pemangku kepentingan lain.

3. Responsibilitas (Responsibility)

Perusahaan seharusnya mematuhi peraturan perundang-undangan serta melaksanakan tanggung jawab terhadap masyarakat dan lingkungan sehingga dapat terpelihara kesinambungan usaha dalam jangka panjang dan mendapat pengakuan sebagai good corporate citizen.

4. Independensi (Independency)

Pengelolaan perusahaan secara independen sehingga masing-masing organ perusahaan tidak saling mendominasi dan tidak dapat diintervensi oleh pihak lain.

5. Kewajaran dan Kesetaraan (Fairness)

Perusahaan dalam melaksanakan kegiatannya harus senantiasa memerhatikan kepentingan pemegang saham dan pemangku kepentingan lainnya berdasarkan asas kewajaran dan kesetaraan.

\section{Dewan Komisaris}

Dewan komisaris sebagai wakil pemegang saham memiliki tugas untuk melakukan pengawasan dan memberikan nasihat kepada direksi dalam menjalankan kegiatan perusahaan (Wignjoharjoto, 2001 seperti yang ditulis oleh Wulandari dan Septiari, 2015). Menurut Egon
Zehnder (2000) dalam Meilinda (2013), dewan komisaris merupakan inti dari corporate governance, yang ditugaskan untuk menjamin pelaksanaan strategi perusahaan, mengawasi manajemen dalam mengelola perusahaan, serta mewajibkan terlaksananya akuntabilitas.

\section{Dewan Komisaris Independen}

Komisaris independen merupakan komisaris yang bukan merupakan anggota manajemen, pemegang saham mayoritas, pejabat atau berhubungan langsung maupun tidak langsung dengan pemegang saham mayoritas dari suatu perusahaan tersebut (Surya dan Yustiavandana, 2006 dalam Wulandari dan Septiari, 2015).

\section{Kepemilikan Institusional}

Kepemilikan institusional merupakan kondisi dimana institusi memiliki saham dalam suatu perusahaan. Institusi tersebut dapat berupa institusi pemerintah, institusi swasta, domestik maupun asing (Widarjo, 2010 dalam Pujiati, 2015). Kepemilikan institusional merupakan satu diantara alat yang dapat digunakan untuk mengurangi agency problem serta memiliki kemampuan untuk mengendalikan pihak manajemen melalui proses monitoring secara efektif (Yunitasari, 2014).

\section{Kepemilikan Manajerial}

Kepemilikan manajerial adalah kepemilikan saham oleh pihak manajemen perusahaan. Kepemilikan saham manajerial dapat mensejajarkan kepentingan antara pemegang saham dengan manajer, karena manajer ikut meraskan langsung manfaat dari keputusan yang diambil dan manajer yang menanggung risiko apabila terdapat kerugian yang timbul sebagai konsekuensi dari pengambilan keputusan yang salah (Yunitasari, 2014).

\section{Komite Audit}

Komite audit adalah komite yang dibentuk oleh dewan komisaris perusahaan, yang anggotanya diangkat dan diberhentikan oleh dewan komisaris. Berdasarkan Keputusan Ketua BAPEPAM Nomor Kep-643/BL/2012, komite audit bertugas untuk memberikan pendapat kepada dewan komisaris terhadap laporan atau hal-hal yang disampaikan oleh direksi kepada dewan komisaris, mengidentifikasi hal-hal yang memerlukan 
perhatian komisaris, dan melaksanakan tugas-tugas lain yang berkaitan dengan tugas dewan komisaris.

\section{Hipotesis \\ Pengaruh Ukuran Dewan Komisaris terhadap Manajemen Pajak \\ Dewan komisaris sebagai wakil pemegang saham bertugas untuk mengawasi manajemen sebagai pengelola perusahaan serta memberikan arahan dan nasihat atas kebijakan yang dibuat, termasuk bagaimana perusahaan tersebut membuat keputusan mengenai segala bentuk transaksi yang tidak lepas dari pajak. Minnick dan Noga (2010) dalam Meilinda (2013) menyatakan bahwa jumlah dewan komisaris yang sebih sedikit akan membuat dewan lebih fokus untuk meyakinkan manajemen agar berinvestasi dalam manajemen pajak. Ukuran dewan komisaris yang besar dan tidak seimbang dengan ukuran perusahaan akan menyulitkan pelaksanaan tugas karena adanya ketidakefektifan dan kesulitan dalam koordinasi dengan anggota dewan yang lain. \\ $\mathrm{H}_{1}$ : Ukuran dewan komisaris berpengaruh positif terhadap manajemen pajak.}

\section{Pengaruh Proporsi Dewan Komisaris terhadap Manajemen Pajak}

Keberadaan dewan komisaris independen sebagai komisaris dari pihak luar dengan sikap objektif dan netral sangat diperlukan untuk menunjang kerja dewan komisaris dalam mengawasi operasional perusahaan.komisaris independen bersama komisaris yang lain dapat bekerja sama dan saling berkoordinasi untuk menajlankan fungsi pengawasan dan menentukan kebijakan dalam perusahaan agar dalam kegiatannya tidak melanggar hukum atau peraturan yang ditetapkan, termasuk mengenai manajemen pajak.

Bonazzi dan Islam (2007) dalam Hanum (2013) menyatakan bahwa peran pengawasan yang baik dilakukan oleh dewan luar perusahaan dan direktur independen terhadap kinerja manajerial dan perusahaan secara keseluruhan, dimana para dewan luar dan direktur perusahaan mengawasi perusahaan agar beroperasi sesuai dengan jalurnya dan tidak bertentangan dengan hukum. Dewan komisaris independen akan membantu perumusan strategi dan pengambilan keputusan agar mendapat hasil yang efektif dan tidak bertentangan dengan hukum yang berlaku, termasuk mengenai manajemen pajak. Semakin banyak proporsi dewan komisaris akan memberikan masukan kepada manajemen agar melakukan manajemen pajak yang efektif, sehingga pajak secara kas yang di bayar semakin kecil.

$\mathrm{H}_{2}$ : Proporsi dewan komisaris independen berpengaruh terhadap manajemen pajak.

\section{Pengaruh Kepemilikan Institusional terhadap Manajemen Pajak}

Kepemilikan institusional memiliki beberapa kelebihan seperti dijelaskan Sandy dan Lukviarman (2015), yaitu terdapat profesionalisme dalam menganalisis informasi sehingga dapat menguji keandalan informasi dan terdapat motivasi yang kuat untuk melaksanakan pengawasan lebih ketat atas aktivitas yang terjadi di dalam perusahaan, sehingga dapat dikatakan kepemilikan institusional dapat mendorong manajemen agar perusahaan dalam menghasilkan laba berdasarkan peraturan yang berlaku (Wulandari dan Septiari, 2015) karena investor institusional lebih melihat seberapa jauh manajemen taat kepada aturan dalam menghasilkan laba dan tidak ingin mendapat kerugian sebagai dampak dari pelanggaran hukum yang dilakukan perusahaan.

$\mathrm{H}_{3}$ : Kepemilikan institusional berpengaruh positif terhadap manajemen pajak.

\section{Pengaruh Kepemilikan Manajerial terhadap Manajemen Pajak}

Kepemilikan manajerial merupakan kepemilikan saham oleh pihak manajemen dari seluruh modal saham perusahaan yang dikelola (Boediono, 2005 dalam Wulandari dan Septiari, 2015). Dengan adanya kepemilikan manajerial diharapkan manajemen semakin termotivasi untuk meningkatkan kinerja perusahaan melalui efisiensi pembayaran pajak. Semakin banyak kepemilikan manajerial dalam perusahaan menunjukkan banyaknya saham yang ada di perusahaan oleh pihak manajemen sendiri, sehingga manajemen mempunyai sikap untuk dapat melakukan manajemen pajak yang dapat menurunkan besarnya pajak yang di setor. Nilai pajak yang disetor semakin kecil menunjukkan perusahaan efektif dalam melakukan manajemen pajak. Karena manajemen pajak diukur dari pembayaran pajak secara kas/tunai dalam laporan arus kas di bagi dengan laba sebelum pajak. 
$\mathrm{H}_{4}$ : Kepemilikan manajerial berpengaruh negatif terhadap manajemen pajak.

\section{Pengaruh Komite Audit terhadap Manajemen Pajak}

Tugas dari komite audit adalah membantu dewan komisaris dalam melakukan pengawasan terhadap kinerja perusahaan, dengan kata lain komite audit berfungsi sebagai jembatan penghubung antara perusahaan dengan eksternal auditor (Winata, 2014), sehingga komite audit dapat mengurangi pengukuran dan pengungkapan akuntansi yang tidak tepat dan akan meminimalisasi tindakan yang melanggar hukum dalam perusahaan. Semakin banyak jumlah komite audit maka nilai ETR akan semakin tinggi.

$\mathrm{H}_{5}$ : Komite audit berpengaruh positif terhadap manajemen pajak.

\section{Model Analisis}

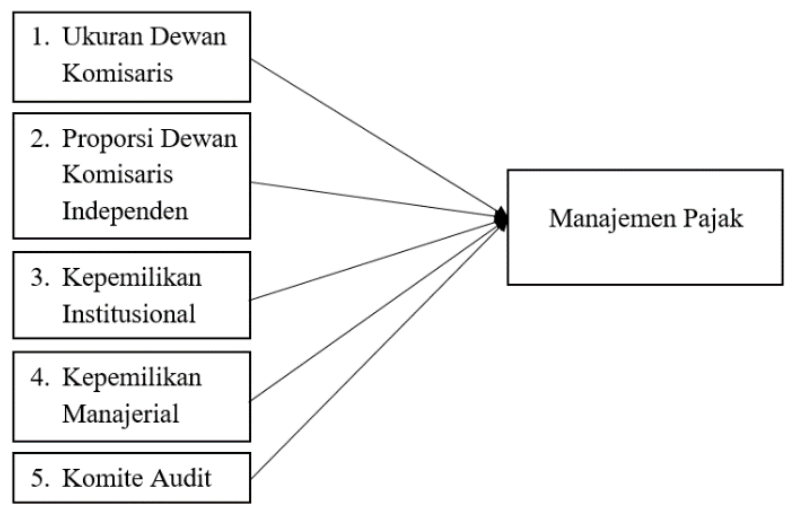

Gambar 1

Kerangka Konseptual

\section{METODE PENELITIAN \\ Pendekatan Penelitian}

Penelitian ini merupakan penelitian deskriptif kuantitatif yaitu penelitian yang bertujuan untuk mengetahui hubungan antara dua variabel atau lebih. Data yang digunakan yaitu data sekunder yang berasal dari laporan keuangan perusahaan pada sektor perdagangan, jasa, dan investasi yang terdaftar di Bursa Efek Indonesia (selanjutnya disebut BEI) selama periode 2014-2016. Laporan keuangan tahunan diperoleh dari website Bursa Efek Indonesia www.idx.co.id.

\section{Populasi dan Sampel}

Populasi dalam penelitian ini adalah perusahaan sektor perdagangan, jasa, dan investasi yang terdaftar di BEI untuk periode 2014-2016. Pengambilan sampel dilakukan dengan metode purposive sampling, yaitu teknik penentuan sampel dengan pertimbangan tertentu. Adapun kriteria yang diambil oleh peneliti antara lain:

1. Perusahaan subsektor perdagangan besar, perdagangan eceran, serta perusahaan subsektor pariwisata, restoran, dan hotel yang terdaftar di BEI tahun 2014-2016.

2. Perusahaan tercatat di BEI sebelum periode pengamatan dan menerbitkan laporan keuangan selama periode tahun 2014-2016 secara berturut-turut.

3. Perusahaan menyajikan laporan keuangan dengan menggunakan mata uang rupiah, agar perbandingan dan analisis dapat dilakukan dengan mudah.

4. Perusahaan sampel memiliki laba setelah pajak bernilai positif selama tahun 2014-2016, agar pengukuran manajemen pajak mendapatkan hasil yang representatif.

5. Perusahaan mengungkapkan jumlah cash tax paid pada laporan arus kas, agar pengukuran CETR dapat dilakukan.

\section{Definisi Operasional Variabel}

1. Ukuran Dewan Komisaris COMSIZE $=\sum$ Seluruh anggota dewan konisaris

2. Proporsi Dewan Komisaris Independen INDEP $=\frac{\text { ¿Komisaris independen }}{\sum \text { Seluruh anggota dewan komisaris }} \times 100 \%$

3. Kepemilikan Institusional JNST $=\frac{\sum \text { Saham institusi }}{\sum \text { Saham beredar }} \times 100 \%$

4. Kepemilikan Manajerial MNIR $=\frac{\sum \text { Saham direksi }}{\sum \text { Saham beredar }} \times 100 \%$ 
5. Komite Audit

$$
\text { AUD }=\sum \begin{aligned}
& \text { Seluruh anggota yang tergabung dalam } \\
& \text { komite audit }
\end{aligned}
$$

6. Manajemen Pajak

Manajemen pajak dalam penelitian ini diukur dengan CETR, agar dapat mengetahui besarnya pajak yang dibayar secara tunai dibanding besarnya Laba sebelum pajak.

$$
\text { CETR }=\frac{\sum \text { Cash taxes prid }}{\sum \text { Pretax } \text { income }}
$$

\section{Pengolahan Data}

Penelitian ini menggunakan model data panel yang diolah dengan bantuan program Eviews 8. Pengolahan statistik dalam penelitian ini meliputi analisis statistik deskriptif yang dilanjutkan dengan pengujian asumsi klasik, pemilihan model estimasi, dan terakir dilakukan pengujian hipotesis.

\section{Statistik Deskriptif}

Statistik deskriptif yang digunakan dalam penelitian ini adalah nilai rata-rata (mean), nilai maksimum, nilai minimum, dan standar deviasi.

\section{Uji Asumsi Klasik}

Syarat pengujian regresi linier berganda adalah harus memenuhi syarat-syarat yaitu lolos dari uji asumsi klasik yang meliputi:

\section{Uji Normalitas}

Uji normalitas bertujuan untuk mengetahui apakah data yang digunakan dalam penelitian memiliki distribusi normal atau tidak. Untuk menguji normalitas data dalam penelitian ini diketahui dengan menggunakan uji jarque berra dengan menggunakan Eviews 8. Secara praktis dengan menggunakan perangkat Eviews 8 , data dikatakan berdistribusi normal jika probabilitas JB > 5\% dengan interval keyakinan 95\% (Wahyuni, Ernawati, dan Murhadi, 2013).

2. Uji Multikoliniearitas

Pengujian multikolinearitas bertujuan untuk mengetahui apakah dalam model regresi terdapat korelasi antar variabel independen. Multikolinearitas dapat di deteksi dengan menggunakan correlation matrix (matriks korelasi). Jika hasil pengujian multikolinearitas menunjukan hasil yang tinggi $(>0,8)$ maka menunjukan bahwa data tersebut terdapat indikasi multikolinearitas (Putra Irawan, 2012).

3. Uji Autokorelasi

Uji autokorelasi digunakan untuk mengetahui korelasi antara anggota serangkaian data observasi baik data time series maupun cross sectional. Terjadinya autokorelasi menyebabkan uji $\mathrm{F}$ dan uji $\mathrm{t}$ menjadi tidak akurat. Untuk mendeteksi autokorelasi, dapat dilakukan dengan menggunakan uji durbin watson (DW). Apabila angka DW sebesar < 1,10 maka terdapat autokorelasi, apabila antara 1,10-1,54 maka tanpa kesimpulan, apabila 1,552,46 tidak ada autokorelasi, serta apabila 2,462,9 tanpa kesimpulan, dan apabila > 2,9 terdapat autokorelasi (Asiah, Jamilah, dan Kristiningsih, 2016).

4. Uji Heteroskedastisitas

Uji ini dimaksudkan untuk mengetahui apakah terjadi penyimpangan model karena variance gangguan berbeda antara satu observasi ke observasi lain (Asiah, Jamilah, dan Kristiningsih, 2016). Pada Eviews 8 tidak menyediakan tools spesifik untuk menguji heteroskedastisitas pada data panel, namun pendekatan dengan menerapkan white crosssection pada metode koefisien kovarian ketika akan melakukan estimasi regresi, dapat menunjukkan adanya gejala heteroskedastisitas pada sampel penelitian. Jika terdapat perbedaan terhadap standard error dan nilai t-statistik, maka dapat disimpulkan bahwa terdapat gejala heteroskedastisitas. Apabila terdapat masalah ini dalam model, maka dilakukan pengobatan dengan menggunakan model generalized least square.

\section{Pemilihan Model Estimasi}

Pengolahan data panel dengan bantuan program Eviews 8 dapat menggunakan pendekatan model regresi dari data panel, yaitu model common effect, model fixed effect, dan model random effect, yang untuk selanjutnya dipilih mana yang merupakan model terbaik. Pemilihan model tersebut harus melalui tiga tahap uji yang meliputi uji chow untuk memilih antara model pooled least square atau fixed effect. Kedua, uji lagrange multiplier (LM) untuk memilih antara model pooled least square atau random effect. Ketiga, uji hausman untuk memilih metode yang paling tepat antara fixed effect dan random effect model.

Uji chow menguji hipotesis sebagai berikut:

\section{$\mathrm{H}_{0}$ : Pooled least square}

$\mathrm{H}_{1}$ : Fixed effect

Bila probabilitas $\mathrm{F}<\alpha=0,05$ maka $\mathrm{H}_{0}$ ditolak. Dengan demikian model penelitian menggunakan metode pengolahan fixed effect.

Pada uji lagrange multiplier, hipotesis yang digunakan adalah sebagai berikut:

$\mathrm{H}_{0}$ : Pooled least square 


\section{$\mathrm{H}_{1}$ : Random effect}

Dasar penolakan $\mathrm{H}_{0}$ menggunakan statistik LM test yang berdasarkan distribusi chi square. Jika $L M$ statistic lebih besar dari chi square table, maka tolak $\mathrm{H}_{0}$ sehingga model yang lebih sesuai dalam menjelaskan dalam permodelan data panel tersebut adalah model pooled least square, begitu pula sebaliknya.

Apabila dari hasil uji chow menunjukkan bahwa penggunaan model fixed effect lebih tepat, maka langkah selanjutnya adalah melakukan uji hausman untuk melihat apakah model mengikuti model random effect atau model fixed effect. Hipotesis dalam uji ini adalah:

$\mathrm{H}_{0}$ : model mengikuti random effect

$\mathrm{H}_{1}$ : model mengikuti fixed effect

Bila probabilitas $<\alpha=0,05$ maka $\mathrm{H}_{0}$ ditolak. Dengan demikian model penelitian yang digunakan adalah metode pengolahan fixed effect.

\section{Analisis Regresi Berganda}

Dalam penelitian ini, analisis regresi berganda digunakan untuk memprediksi hubungan antara corporate governance dengan effective tax rate (ETR). Adapun persamaan untuk untuk menguji hipotesis secara keseluruhan pada penelitian ini adalah sebagai berikut:

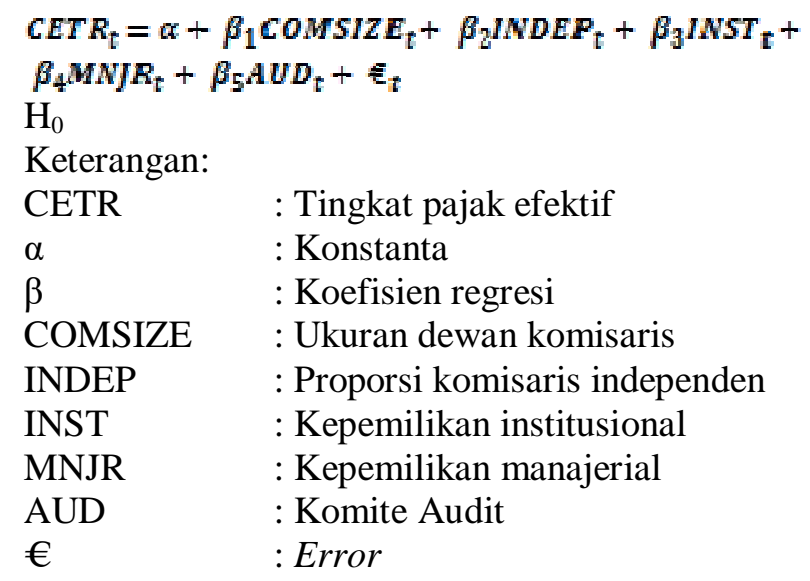

\section{Pengujian Hipotesis}

Secara statistik, pengujian hipotesis ini dapat diukur dari nilai koefisien determinasi $\left(\mathrm{R}^{2}\right)$, nilai statistik F, dan nilai statistik t.

Koefisien determinasi $\left(\mathrm{R}^{2}\right)$ digunakan untuk mengukur seberapa jauh kemampuan model dalam menerangkan variasi variabel independen. Nilai $R^{2}$ yang kecil berarti kemampuan variabel-variabel independen dalam menjelaskan variasi variabel dependen amat terbatas.

Menurut Ghozali (2006), Uji statistik F digunakan untuk mengetahui apakah semua variabel independen atau bebas yang dimasukkan dalam model mempunyai pengaruh secara bersama-sama (simultan) terhadap variabel dependen atau terikat. (Ghozali, 2006 dalam Meilinda, 2013). Dengan tingkat signifikansi 0,05 $(5 \%)$, maka kriteria pengujian adalah sebagai berikut:

1. Bila nilai signifikansi $\mathrm{F}<0.05$, maka $\mathrm{H}_{0}$ ditolak, artinya terdapat pengaruh antara semua variabel independen terhadap variabel dependen.

2. Bila nilai signifikansi $\mathrm{F}>0.05$, maka $\mathrm{H}_{0}$ diterima, artinya semua variabel independen tidak berpengaruh terhadap variabel dependen.

Uji statistik $t$ digunakan untuk mengetahui seberapa jauh pengaruh satu variabel independen secara individual dalam menjelaskan variasi variabel dependen (Ghozali, 2006 dalam Meilinda, 2013). Dalam penelitian ini menggunakan tingkat signifikansi sebesar 0,05. Penolakan atau penerimaan hipotesis berdasarkan kriteria sebagai berikut:

$\alpha>0,05$ : tidak mampu menolak $\mathrm{H}_{0}$, dan $\alpha<0,05$ : menolak $\mathrm{H}_{0}$

\section{PEMBAHASAN}

\section{Deskripsi Sampel Penelitian}

Sampel yang digunakan pada penelitian ini adalah perusahaan pada subsektor perdagangan besar, perdagangan eceran, serta perusahaan pariwisata, restoran, dan hotel selama periode 2014-2016 dengan kriteria tertentu. Berdasarkan IDX Statistics 2016, terdapat 81 perusahaan yang termasuk dalam subsektor tersebut. Seleksi sampel menghasilkan 33 perusahaan dengan rincian 12 perusahaan dari subsektor perdagang besar, 10 perusahaan dari subsektor perdagangan eceran, dan 11 perusahaan yang termasuk dalam subsektor pariwisata, hotel, dan restoran. Periode pengamatan masing-masing perusahaan adalah tiga tahun, sehingga jumlah sampel dalam penelitian ini berjumlah 99 . 
Tabel 1

Statistik Deskriptif

\begin{tabular}{lrrrrrr}
\hline & CETR & COMSIZE & \multicolumn{1}{c}{ INDEP } & \multicolumn{1}{l}{ INST } & \multicolumn{1}{l}{ MNJR } & \multicolumn{1}{c}{ AUD } \\
\hline Mean & 0.867860 & 4.515152 & 0.387386 & 0.673855 & 0.003995 & 2.969697 \\
\hline Median & 0.331729 & 5.000000 & 0.400000 & 0.656300 & 0.000000 & 3.000000 \\
\hline Maximum & 22.60713 & 9.000000 & 0.600000 & 0.989660 & 0.060000 & 4.000000 \\
\hline Minimum & 0.028843 & 2.000000 & 0.200000 & 0.174800 & 0.000000 & 2.000000 \\
\hline Std. Dev. & 2.799619 & 1.402357 & 0.079864 & 0.201965 & 0.010797 & 0.223814 \\
\hline Observations & 99 & 99 & 99 & 99 & 99 & 99 \\
\hline
\end{tabular}

(Sumber : pengolahan data dari program Eviews 8)

\section{Statistik Deskriptif}

Dari hasil statistik deskriptif, dapat diketahui rata-rata CETR yang merupakan proksi dari manajemen pajak menunjukkan nilai sebesar 0,867860 dengan standar deviasi 2,799619, artinya rata-rata perusahaan membayar pajak melalui kas lebih dari $86 \%$ dari nilai laba sebelum pajak.

Rata-rata ukuran dewan komisaris (COMSIZE) menunjukkan nilai 4,515152 dengan standar deviasi sebesar 1,402357 yang berarti ukuran dewan komisaris cukup bervariatif. Ukuran dewan komisaris terkecil adalah 2 orang, sedangkan ukuran terbesar adalah 9 orang.

Rata-rata pada variabel proporsi dewan komisaris independen (INDEP) menunjukkan nilai sebesar 0,387386 (39\%) yang berarti rata-rata perusahaan memiliki jumlah anggota dewan komisaris independen sesuai dengan aturan yang diwajibkan, yaitu sekurang-kurangnya $30 \%$ dari seluruh anggota yang tergabung dalam dewan komisaris.

Kepemilikan institusional (INST) memiliki rata-rata sebesar 0,673855 dengan standar deviasi 0,201965 menunjukkan bahwa $67 \%$ saham perusahaan sampel rata-rata dimiliki oleh institusi lain.
Rata-rata kepemilikan manajerial (MNJR) adalah sebesar 0,003995 dengan standar deviasi 0,010797 menunjukkan bahwa 0,39\% saham pada perusahaan sampel dimiliki oleh pihak manajemen.

Jumlah komite audit (AUD) pada perusahaan sampel menunjukkan rata-rata 2,969697 (tiga orang) dengan standar deviasi sebesar 0,223814 yang berarti rata-rata perusahaan sampel memiliki komite audit dengan jumlah tiga orang, nilai standar deviasi menunjukkan bahwa nilai tersebut tidak terlalu bervariatif antar sampel.

\section{Hasil Pengujian Asumsi Klasik Uji Normalitas}

Hasil pengujian normalitas dengan menggunakan jarque-bera menunjukkan bahwa nilai probabilitas sebesar 0,000000 . Nilai tersebut menunjukkan bahwa data tidak terdistribusi secara normal dikarenakan nilai signifikansi yang lebih kecil dari 0,05 . Untuk itu perlu dilakukan perlakuan tertentu agar data dapat terdistribusi dengan normal. Perlakuan terhadap data yang tidak normal adalah dengan melakukan transformasi atau mengubah data ke dalam bentuk ln (logaritma natural) untuk memperkecil skala ukuran data dan untuk menormalkan distribusi data, sehingga tampak pada gambar 3 yang menunjukkan bahwa data telah terdistribusi normal.

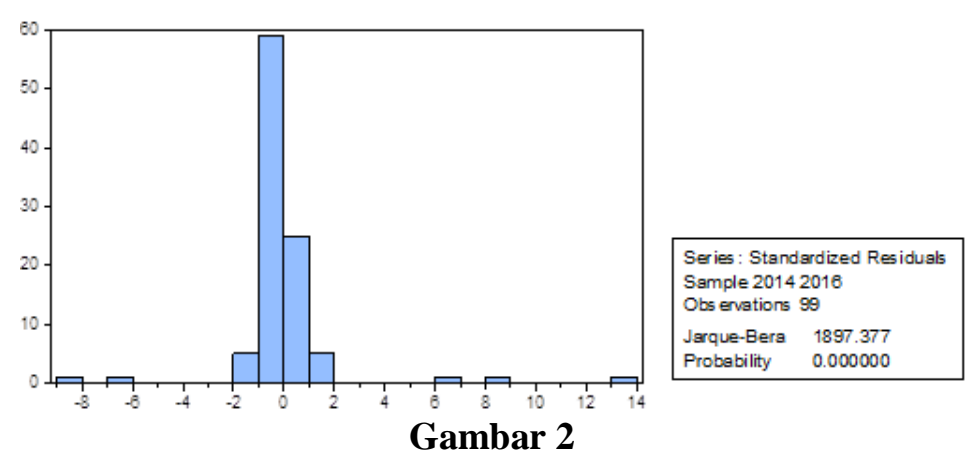

Uji Normalitas dengan Metode Pooled Least Square

(Sumber : Pengolahan data dari program Eviews 8) 


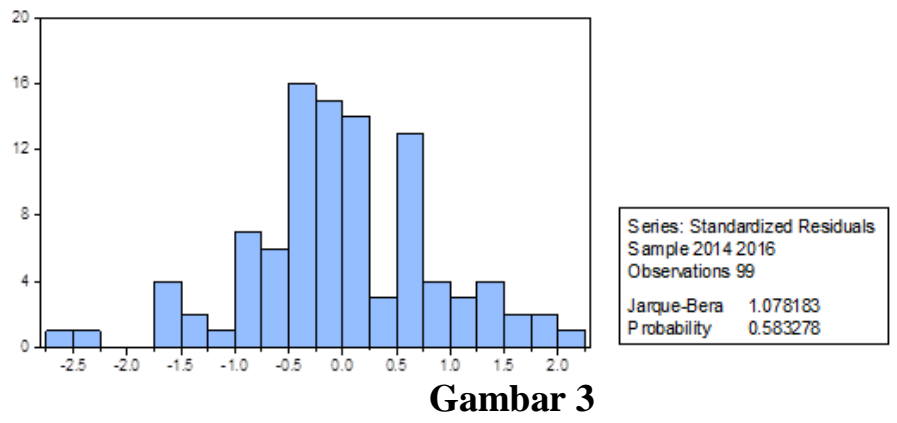

Uji Normalitas dengan Metode Pooled Least Square

(Sumber : Pengolahan data dari program Eviews 8)

\section{Uji Multikoliniearitas}

Pengujian multikolinearitas dilakukan untuk mengetahui ada atau tidaknya hubungan antarvariabel independen dalam model regresi. Uji multikolinearitas dalam penelitian ini juga diolah menggunakan program Eviews 8. Pada tabel 2 tampak bahwa tidak terdapat nilai korelasi yang lebih tinggi dari 0,8 atau lebih rendah dari $-0,8$ antar variabel independen, maka data yang digunakan dalam penelitian ini bebas dari multikolinearitas.

Tabel 2

Hasil Uji Multikolinearitas

\begin{tabular}{lccccc}
\hline & COMSIZE & INDEP & INST & MNJR & AUD \\
\hline COMSIZE & 1.000000 & & & & \\
\hline$I N D E P$ & 0.258621 & 1.000000 & & & \\
\hline$I N S T$ & -0.089102 & 0.034015 & 1.000000 & & \\
\hline$M N J R$ & -0.137712 & -0.088549 & -0.087614 & 1.000000 & \\
\hline AUD & 0.017733 & -0.097719 & 0.006584 & 0.050608 & 1.000000 \\
\hline
\end{tabular}

(Sumber: pengolahan data dari program Eviews 8)

\section{Uji Autokorelasi}

Gejala autokorelasi dapat dideteksi menggunakan durbin watson test, namun karena model dianalisis dengan data panel, pengujian autokorelasi tidak dilakukan pada data observasi yang digunakan dalam penelitian ini (Nachrowi, 2006 dalam Irawan, 2015).

\section{Uji Heteroskedastisitas}

Dampak adanya heteroskedastisitas adalah tidak efisiennya proses estimasi, sehingga untuk mengetahui apakah terjadi heteroskedastisitas maka terlebih dahulu dilakukan pemilihan model regresi. Pendekatan dengan menerapkan white cross-section pada metode koefisien kovarian ketika akan melakukan estimasi regresi, dapat menunjukkan adanya gejala heteroskedastisitas pada sampel penelitian. Jika terdapat perbedaan terhadap standard error dan nilai t-statistik maka dapat disimpulkan bahwa terdapat gejala heteroskedastisitas.

Pemilihan model estimasi yang dilakukan dengan uji chow dan uji hausman seperti pada tabel 5 dan 6 menunjukkan bahwa model regresi terbaik adalah dengan menggunakan fixed effect, sehingga dapat dilakukan uji heteroskedastisidas.

Tabel 3

Fixed Effect Model Ordinary Method (no weight)

\begin{tabular}{lccc}
\hline \multicolumn{1}{c}{ Variable } & Coefficient & Std. Error & t-Statistic \\
\hline C & -2.122943 & 2.655544 & -0.799438 \\
\hline COMSIZE & 0.166951 & 0.167828 & 0.994776 \\
\hline INDEP & 1.444022 & 2.464394 & 0.585954 \\
\hline INST & -0.565924 & 2.331162 & -0.242765 \\
\hline MNJR & 7.665048 & 21.30391 & 0.359795 \\
\hline AUD & 0.063346 & 0.621023 & 0.102002 \\
\hline
\end{tabular}

(Sumber: : pengolahan dengan program Eviews 8) 
Tabel 4

Fixed Effect Model White Cross Section Method (no weight)

\begin{tabular}{lccc}
\hline \multicolumn{1}{c}{ Variable } & Coefficient & Std. Error & t-Statistic \\
\hline C & -2.122943 & 1.117593 & -1.899567 \\
\hline COMSIZE & 0.166951 & 0.019643 & 8.499167 \\
\hline INDEP & 1.444022 & 0.276318 & 5.225945 \\
\hline INST & -0.565924 & 0.578505 & -0.978252 \\
\hline MNJR & 7.665048 & 1.136550 & 6.744134 \\
\hline AUD & 0.063346 & 0.167573 & 0.378017 \\
\hline
\end{tabular}

(Sumber: : pengolahan dengan program Eviews 8)

Pada tabel 3 dan tabel 4 dapat dilihat perbandingan antara fixed effect model ordinary method dengan fixed effect model white cross section method yang menunjukkan bahwa nilai koefisien tetap, namun terjadi perubahan pada nilai standard error dan $t$-statistic yang membuat estimasi tidak efisien. Hal ini menunjukkan adanya gejala heterokedastisitas sehingga akan digunakan pembobotan untuk mengatasinya, yaitu dengan menggunakan cross section weight pada GLS white dan white cross-section pada coefficient covariance method, selanjutnya hasil pengujian regresi dengan pembobotan adalah model regresi yang digunakan sebagai dasar analisis dalam penlitian. Hasil pengujian regresi liniear berganda dapat dilihat pada tabel 7.

Tabel 5

Hasil Uji Chow

\begin{tabular}{lc}
\hline \multicolumn{2}{c}{ Redundant Fixed Effects Tests } \\
\hline Effects Test & Prob. \\
\hline Cross-section F & 0.0002 \\
\hline Cross-section Chi-square & 0.0000 \\
\hline
\end{tabular}

(Sumber: pengolahan dengan Eviews 8)

Tabel 6

Hasil Uji Hausman

$\frac{3 \text { Correlated Random Effects - Hausman Test }}{\text { Test Summary }}$

\section{Pemilihan Model Estimasi}

Seperti yang dapat dilihat pada tabel 5, nilai probabilitas untuk cross-section $F=0,0002$ yang berarti kurang dari 0,05 , maka $\mathrm{H}_{0}$ ditolak, sehingga dapat disimpulkan dengan tingkat keyakinan $95 \%$ model fixed effect lebih baik daripada model common effect/partial least square.

Pada tabel 6, dapat dilihat nilai probabilitas cross-section and random period sebesar 0,0314 yang berarti kurang dari 0,05 , maka $\mathrm{H}_{0}$ ditolak, sehingga dapat disimpulkan dengan tingkat keyakinan $95 \%$ model fixed effect lebih baik daripada model random effect.

\section{Hasil Pengujian Regresi Berganda}

Setelah melalui uji chow dan uji hausman, diketahui bahwa model yang terbaik adalah fixed effect model. Sebelum menganalisis hasil regresi dari fixed effect model, perlu diuji terlebih dahulu apakah terdapat heteroskedastisitas. Hal ini dapat dilakukan dengan mengubah coefficient covariance method menjadi white cross-section dan dilakukan pengamatan terhadap nilai standard error dan nilai $t$-statistic dari model yang digunakan. Pengujian heteroskedastisitas yang dilakukan dengan membandingkan regresi pada tabel 3 dan 4 menunjukkan adanya gejala heteroskedastisitas sehingga dilakukan pembobotan dan menghasilkan model regresi seperti pada tabel 7 . 
Persamaan regresi pada tabel 7 menunjukkan nilai konstanta sebesar -2,249942, yang berarti berarti bahwa ketika variabel independen bernilai 0, maka nilai CETR sebesar -2,249942. Konstanta yang bernilai negatif dapat diabaikan karena uji asumsi klasik telah terpenuhi.

Variabel COMSIZE memiliki nilai koefisien sebesar 0,145914. Nilai ini menunjukkan bahwa terdapat pengaruh positif antara perubahan variabel ukuran dewan komisaris dengan perubahan CETR.

Variabel INDEP memiliki nilai koefisien sebesar 0,845318. Nilai ini menunjukkan bahwa terdapat pengaruh positif antara perubahan variabel proporsi dewan komisaris independen dengan perubahan CETR.
Variabel INST memiliki nilai koefisien sebesar 0,169339. Nilai ini menunjukkan bahwa terdapat pengaruh positif antara perubahan variabel kepemilikan institusional dengan perubahan CETR.

Variabel MNJR memiliki nilai koefisien sebesar 7,213279. Nilai ini menunjukkan bahwa terdapat pengaruh positif antara perubahan variabel kepemilikan manajerial dengan perubahan CETR.

Variabel AUD memiliki nilai koefisien sebesar 0,049964. Nilai ini menunjukkan bahwa terdapat pengaruh positif antara perubahan variabel komite audit dengan perubahan CETR.

CETR $=-2.249942+0.145914$ COMSIZE + 0.845318 INDEP + 0.169339 INST + 7.213279 MNJR + 0.049964 AUD.

Tabel 7

Hasil Uji Regresi Fixed Effect Model White Cross Section Method (weighted)

\begin{tabular}{lccc}
\hline \multicolumn{1}{c}{ Variable } & Coefficient & Prob. & Hipotesis \\
\hline $\mathrm{C}$ & -2.249942 & 0.0026 & \\
\hline COMSIZE & 0.145914 & 0.0000 & + \\
\hline INDEP & 0.845318 & 0.0000 & + \\
\hline INST & 0.169339 & 0.5840 & + \\
\hline MNJR & 7.213279 & 0.0000 & - \\
\hline AUD & 0.049964 & 0.8220 & + \\
\hline
\end{tabular}

Effects Specification

\begin{tabular}{ll}
\hline$R$-squared & 0.899218 \\
\hline Adjusted $R$-squared & 0.838088 \\
\hline F-statistic & 14.70987 \\
\hline Prob (F-statistic) & 0.000000 \\
\hline
\end{tabular}

(Sumber: pengolahan dengan Eviews 8

\section{Hasil Pengujian Hipotesis}

\section{Uji Koefisien Determinasi $\left(\mathbf{R}^{2}\right)$}

Dari tabel 7 dapat diketahui nilai Adjusted $R$ Square $\left(\mathrm{R}^{2}\right)$ sebesar 0,838088 yang berarti dapat disimpulkan bahwa variabel dependen (manajemen pajak) dapat dijelaskan dengan baik oleh variabel independen (ukuran dewan komisaris, proporsi komisaris independen, kepemilikan institusional, kepemilikan manajerial, dan komite audit).

\section{Uji Signifikansi Stimultan (Uji Statistik F)}

Berdasarkan data tabel 7, terlihat bahwa nilai $\mathrm{F}$ sebesar 14,70987 dengan tingkat hasil signifikansi sebesar 0,000000. Hasil tersebut berada dibawah tingkat probabilitas yang ditentukan yaitu 0,05 , maka variabel ukuran dewan komisaris, proporsi komisaris independen, kepemilikan institusional, kepemilikan manajerial, dan komite audit berpengaruh secara serentak (stimultan) pada manajemen pajak.

\section{Uji Signifikansi Parameter Individual (Uji Statistik t)}

Pada persamaan regresi linear, variabel COMSIZE memiliki nilai positif dengan taraf signifikansi sebesar 0,0000. Dengan tingkat $\alpha<$ $5 \%$, maka variabel ukuran dewan komisaris ini dapat disimpulkan berpengaruh positif terhadap CETR, sehingga $\mathrm{H}_{1}$ diterima.

Pada persamaan regresi linear, variabel INDEP memiliki nilai positif dengan taraf signifikansi sebesar 0,0000. Dengan tingkat $\alpha<5 \%$, maka variabel proporsi dewan komisaris independen ini 
dapat disimpulkan berpengaruh positif terhadap CETR, sehingga $\mathrm{H}_{2}$ diterima.

Pada persamaan regresi linear, variabel INST memiliki nilai positif dengan taraf signifikansi sebesar 0,5840. Dengan tingkat $\alpha>5 \%$ maka variabel kepemilikan institusional ini dapat disimpulkan tidak berpengaruh terhadap CETR, sehingga $\mathrm{H}_{3}$ ditolak.

Pada persamaan regresi linear, variabel MNJR memiliki nilai positif dengan taraf signifikansi sebesar 0,0000. Dengan tingkat $\alpha<5 \%$ maka variabel kepemilikan manajerial ini dapat disimpulkan berpengaruh positif terhadap CETR, sehingga $\mathrm{H}_{4}$ diterima.

Pada persamaan regresi linear, variabel AUD memiliki nilai positif dengan taraf signifikansi sebesar 0,8220. Dengan tingkat $\alpha>5 \%$ maka variabel komite audit ini dapat disimpulkan tidak berpengaruh terhadap CETR, sehingga $\mathrm{H}_{5}$ ditolak.

\section{Pengaruh Ukuran Dewan Komisaris terhadap Manajemen Pajak}

Hasil pengujian menunjukkan variabel ukuran dewan komisaris (COMSIZE) memiliki nilai positif dengan taraf signifikansi sebesar 0,0000 sehingga dapat dikatakan bahwa ukuran dewan komisaris memiliki pengaruh positif terhadap manajemen pajak yang diukur dengan CETR. Nilai koefisien positif menunjukkan bahwa penambahan ukuran dewan komisaris akan meningkatkan nilai CETR (tingkat pajak efektif), begitu juga sebaliknya. Dewan komisaris sebagai pihak dengan tanggung jawab besar memiliki dorongan untuk melaksanakan tugas dengan sebaik mungkin dan memastikan bahwa perusahaan menaati peraturan atau hukum yang berlaku, sehingga semakin besar ukuran dewan komisaris, maka manajemen pajak yang terlalu agresif dapat dicegah.

Hasil penelitian ini mendukung penelitian sebelumnya yang dilakukan oleh Meilinda (2013). Hubungan positif ini dapat terjadi karena penambahan dewan komisaris dalam perusahaan dapat mencegah perusahaan melakukan usaha yang agresif dalam manajemen pajak, sehingga perusahaan lebih berhati-hati dalam melakukan aktivitasnya, terkait dengan aturan yang berkaitan dengan pajak.

Wulandari dan Septiari (2015) menyatakan bahwa banyaknya anggota dewan komisaris di suatu perusahaan dapat menimbulkan kesulitan dalam menjalankan peran dan tugas mereka, diantaranya adalah kesulitan dalam berkomunikasi dan mengkoordinir kerja dari masing-masing anggota dewan itu sendiri, kesulitan dalam mengawasi dan mengendalikan tindakan dari manajemen, serta kesulitan dalam mengambil keputusan yang berguna bagi perusahaan, termasuk perumusan strategi yang berhubungan dengan pajak.

\section{Pengaruh Proporsi Dewan Komisaris Independen terhadap Manajemen Pajak}

Hasil pengujian menunjukkan bahwa proporsi komisaris independen (INDEP) memiliki pengaruh positif terhadap manajemen pajak yang diukur dengan CETR. Nilai koefisien positif menunjukkan bahwa penambahan proporsi dewan komisaris independen akan menambah nilai CETR (tingkat pajak efektif), dan juga sebaliknya. Komisaris independen yang menjalankan tugas sebagai pengawas komisaris dalam serta direksi dan sebagai pengamat operasional serta kinerja perusahaan dapat meningkatkan efektivitas pengawasan oleh dewan komisaris, hal tersebut didukung dengan sikap netral dan objektif, sehingga didapatkan hasil yang baik dalam setiap perumusan strategi dan penentuan kebijakan yang dilakukan oleh pihak manajemen. Kesimpulan tersebut memberikan bukti terhadap hipotesis $\mathrm{H}_{2}$ yang diuji dalam penelitian. Keberadaan dewan komisaris independen akan membantu perumusan strategi dan pengambilan keputusan agar mendapat hasil yang efektif dan tidak bertentangan dengan hukum yang berlaku, termasuk mengenai manajemen pajak.

\section{Pengaruh Kepemilikan Institusional terhadap Manajemen Pajak}

Analisis data dan pengujian hipotesis menunjukkan bahwa variabel kepemilikan institusional (INST) memiliki arah positif dan tidak berpengaruh terhadap manajemen pajak yang diukur dengan CETR. Hasil yang positif menunjukkan bahwa kepemilikan institusional mampu mencegah tindakan manajemen pajak yang terlalu agresif. Kepemilikan institusional yang tidak berpengaruh signifikan terhadap manajemen pajak memiliki arti bahwa besar kecilnya kepemilikan institusional dalam suatu perusahaan tidak memengaruhi seberapa efektif perusahaan melakukan manajemen pajak.

Tidak adanya pengaruh antara kepemilikan institusional dengan manajemen pajak dapat terjadi karena investor institusional belum tentu sepenuhnya memiliki informasi yang dimiliki oleh manajer sebagai pengelola perusahaan (Hardiningsih dan Sofyaningsih, 2011) dalam Dewi dan Nugrahanti (2014), yang di tunjukan 
dengan tingkat signifikan lebih besar 0,05. Sehingga investor institusional tidak dapat melakukan kontrol dan memberikan kepercayaan kepada dewan komisaris sebagai wakil pemegang saham untuk menjalankan fungsi pengawasan.

\section{Pengaruh Kepemilikan Manajerial terhadap Manajemen Pajak}

Analisis data dan pengujian hipotesis menunjukkan bahwa variabel kepemilikan manajerial (MNJR) memiliki pengaruh positif terhadap manajemen pajak yang diukur dengan CETR. Hasil yang positif menunjukkan bahwa semakin bertambah persentase kepemilikan manjerial, maka nilai CETR (tingkat pajak efektif) akan semakin meningkat, hal tersebut dapat terjadi karena manajemen selaku pengelola perusahaan mendapat tekanan dari dewan komisaris untuk mengesampingkan kepentingan pribadi dan mematuhi perpajakan yang berlaku. Menurut Hartadinata dan Tjaraka (2013) dalam Atari (2016), menyatakan bahwa kepemilikan saham oleh pihak manajemen pada perusahaan akan membuat manajemen lebih berhati-hati dan mengesampingkan kepentingannya sehingga mencegah penghematan pajak yang terlalu agresif.

\section{Pengaruh Komite Audit terhadap Manajemen Pajak}

Hasil pengujian menunjukkan bahwa komite audit (AUD) memiliki arah positif dan tidak berpengaruh terhadap manajemen pajak yang diukur dengan CETR, sehingga hipotesis $\mathrm{H}_{5}$ ditolak. Hasil yang positif berarti jumlah komite audit dapat memperkuat pengawasan, sehingga manajemen pajak yang agresif dapat dicegah. Hasil yang tidak signifikan menunjukkan penambahan atau pengurangan jumlah komite audit dalam perusahaan tidak membawa pengaruh terhadap tingkat pajak efektif, atau dengan kata lain manajemen pajak yang terlalu agresif masih dapat terjadi. Hasil tersebut dapat terjadi karena komite audit kurang berperan aktif dalam penetapan kebijakan terkait dengan manajemen pajak dan pembentukan dari komite audit yang bersifat mandatory untuk mengikuti peraturan yang berlaku (Kosasih dan Widayati, 2013).

\section{PENUTUP}

\section{Simpulan}

Penelitian ini bertujuan untuk mengkaji pengaruh ukuran dewan komisaris, proporsi komisaris independen, kepemilikan institusional, kepemilikan manajerial, dan komite audit terhadap manajemen pajak yang diukur dengan CETR. Berdasrkan hasil analisis data, dapat disimpulkan bahwa:

1. Ukuran dewan komisaris memiliki pengaruh terhadap manajemen pajak dengan arah positif.

2. Proporsi dewan komisaris independen memiliki pengaruh terhadap manajemen pajak dengan arah positif.

3. Kepemilikan institusional tidak berpengaruh terhadap manajemen pajak.

4. Kepemilikan manajerial memiliki pengaruh terhadap manajemen pajak dengan arah positif.

5. Komite audit tidak berpengaruh terhadap manajemen pajak.

\section{Keterbatasan Penelitian}

Penelitian ini tidak luput dari keterbatasan, keterbatasan dalam penelitian ini adalah hanya menggunakan cash ETR sebagai satu-satunya proksi manajemen pajak dan penelitian ini hanya menggunakan sampel dari perusahaan di sektor perdagangan, jasa, dan investasi, sehingga hasil penelitian tidak dapat digunakan secara umum untuk industri lain di Indonesia. Penelitian ini hanya menggunakan sampel penelitian sebanyak 33 sampel pengamatan dan hanya dalam jangka waktu 3 tahun, sedangkan penilaian kinerja yang berdasarkan laporan keuangan berjangka pendek mempunyai kelemahan bersifat sesaat belum tentu menggambarkan kondisi yang sesungguhnya. Karakteristik corporate governance pada penelitian ini hanya menggunakan lima variabel.

\section{Saran untuk Penelitian Selanjutnya}

Saran untuk penelitian selanjutnya adalah menggunakan atau menambahkan proksi selain cash ETR untuk mengukur aktivitas manajemen pajak seperti GAAP ETR atau current ETR agar dapat digunakan sebagai perbandingan. Penggunaan sampel sebaiknya lebih diperluas untuk seluruh sektor pada Bursa Efek Indonesia sehingga hasil penelitian mampu menggambarkan keadaan di Indonesia dan menambahkan periode pengamatan yang lebih luas untuk agar didapatkan hasil dengan gambaran kondisi yang sesungguhnya, serta akan lebih baik jika ditambahkan variabel karakteristik corporate governance lain seperti $C E O$ tenure dan kualitas audit yang dianggap dapat mencerminkan fungsi pengawasan. Pada penelitian selanjutnya juga diharapkan untuk menambahkan variabel lain yang tidak terkait dengan corporate governance agar mendapatkan pemahaman lebih mendalam 
mengenai faktor-faktor yang memengaruhi manajemen pajak.

\section{DAFTAR PUSTAKA}

Agustania, Engga Hardika. 2016. Pengaruh Ukuran Perusahaan, Profitabilitas, dan Tingkat Hutang Perusahaan terdadap Manajemen Pajak pada Perusahaan Jasa yang Terdaftar di Bursa Efek Indonesia. Skripsi tidak diterbitkan. Universitas Airlangga, Surabaya.

Ardyansah, Danis. 2014. Pengaruh Size, Leverage, Profitability, Capital Intensity Ratio, dan Komisaris Independen terhadap Effective Tax Rate (ETR). Skripsi tidak diterbitkan. Universitas Diponegoro, Semarang. (Online), (eprints.undip.ac.id/42837/), diakses 28 Maret 2018.

Asiah, Siti, Siti Jamilah, dan Kristiningsih. 2016. Metode Penelitian untuk Ilmu Ekonomi. Surabaya: Fakultas Ekonomi Universitas Wijaya Kusuma Surabaya.

Atari, Jeane. 2016. Pengaruh Kepemilikan Manajerial, Kepemilikan Institusional, dan Kebijakan Utang terhadap Tax Aggressive. Jurnal Online Mahasiswa Fakultas Ekonomi Universitas Riau Vo. 3 No.1 (Februari) 2016.

(Online), (media.neliti.com/media/publications/18605 8-ID-pengaruh-kepemilikan-manajerialkepemili.pdf), diakses 20 Juni 2018.

Crowther, D., Seifi S. 2011. Corporate Governance and International Business. Bookbon.com, diakses pada 2 April 2018.

Dewi, Laurensia Chintia dan Yeterina Widi Nugrahanti. 2014. Pengaruh Struktur Kepemilikan dan Dewan Komisaris Independen terhadap Nilai Perusahaan. Kinerja: Journal of Business and Economics Volume 18 No.1, Th. 2014 hal. 64-80. (Online),

(ojs.uajy.index.php/kinerja/article/view/518) , diakses 20 Juni 2018.

Halim, Abdul, Icuk Rangga Bawono dan Amin Dara. 2014. Perpajakan. Jakarta: Salemba Empat.

Irawan, Amri. 2015. Pengaruh Ukuran Perusahaan, Book To Market, Beta, Earning, dan Financial Distress terhadap Subsequent Return Saham (Pada Perusahaan Manufaktur yang Terdaftar di Bursa Efek Indonesia Periode Tahun 20092013). Skripsi tidak diterbitkan. Universitas Islam Negeri Syarif Hidayatullah, Jakarta.
(Online),

(repository.uinjkt.ac.id/dspace/handle/12345 6789/30108), diakses 14 April 2018.

Keputusan Ketua BAPEPAM Nomor Kep643/BL/2012 Tentang Pembentukan dan Pedoman Pelaksanaan Kerja Komite Audit. (Online),

(ojk.go.id/id/regulasi/Documents/Pages/BA PEPAM-IXI5-tentang-Pembentukan-danPedoman-Pelaksanaan-Kerja-KomiteAudit/6.IX.I.5.pdf), diakses 6 April 2018.

Kosasih, Fransiska Natalia dan Catur Widayati. 2013. Pengaruh Independensi Komite Audit, Efektivitas Komite Audit dan Leverage terhadap Praktik Manajemen Laba pada Perusahaan di Sektor Industri Manufaktur yang Terdaftar di BEI Periode 2009-2011. Tarumanegara Journal of Accounting 17 (1), $2012 . \quad$ (Online), (media.neliti.com/media/publications/76927 -ID-none.pdf), diakses 20 Juni 2018.

Lukviarman, Niki. 2004. Etika Bisnis Tak Berjalan di Indonesia: Ada Apa dalam Corporate Governance?. Jurnal Siasat Bisnis No. 9 Vol. 2, Desember 2004. (Online), (journal.uii.ac.id/JSB/issue/view/150), diakses 27 Maret 2018.

Meilinda, Maria. 2013. Pengaruh Corporate Governance terhadap Manajemen Pajak (Studi Empiris pada Perusahaan Manufaktur yang Terdaftar di Bursa Efek Indonesia Tahun 2009-2011). Skripsi tidak diterbitkan. Universitas Diponegoro, Semarang. (Online), (eprints.undip.ac.id/39690/), diakses 20 Maret 2018.

Nazaruddin, Ietje. 2008. Corporate Governance dan Kinerja Perusahaan. Jurnal Akuntansi dan Investasi Vol. 9 No. 2, Juli 2008. (Online),

(journal.umy.ac.id/index.php/ai/issue/view/8 1), diakses 2 April 2018.

Pohan, Chairil Anwar. 2013. Manajemen Perpajakan: Strategi Perencanaan Pajak \& Bisnis. Jakarta: Gramedia Pustaka Utama.

Pujiati. 2015. Pengaruh Kepemilikan Manajerial, Kepemilikan Institusional, dan Kesempatan Investasi terhadap Kebijakan Dividen dengan Likuiditas sebagai Variabel Pemoderasi (Studi Empiris pada Perusahaan Sektor Industri Barang Konsumsi yang Terdaftar di Bursa Efek Indonesia Periode 2008-2013). Skripsi tidak diterbitkan. Universitas Negeri Yogyakarta, 
Yogyakarta.

(Online), (eprints.uny.ac.id/15937/), diakses 5 April 2018.

Putra Irawan, Hendra. 2012. Pengaruh Kompensasi Manajemen dan Corporate Governance terhadap Manajemen Pajak Perusahaan. Skripsi tidak diterbitkan. Universitas Indonesia, Depok. (Online), (http://lib.ui.ac.id/detail?id=20315136\&loka si=lokal), diakses 20 Maret 2018.

Rachmitasari, Annisa. 2015. Pengaruh Return On Assets, Leverage, Corporate Governance, Ukuran Perusahaan dan Kompensasi Rugi Fiskal pada Tax Avoidance. Skripsi tidak diterbitkan. Universitas Muhammadiyah Surakarta. (Online), (eprints.ums.ac.id/36892), diakses 28 Maret 2018.

Sandy, Syeldila dan Niki Lukviarman. 2015. Pengaruh Corporate Governance terhadap Tax Avoidance: Studi Empiris terhadap Perusahaan Manufaktur. Jurnal Akuntansi dan Auditing Indonesia. (Online), (journal.uii.ac.id/JAAI/issue/view/502), diakses 8 April 2018.

Sudana, I Made. 2014. Manajemen Keuangan Teori dan Praktik. Surabaya: Airlangga University Press.

Sudirjo, Frans. 2017. Evaluasi Penerapan Tax Planning untuk Upaya Meminimalkan Beban Pajak dalam Rangka Manajemen Pajak. Prosiding Seminar Nasional \& Call for Pappers $2017 . \quad$ (Online), (feb.untagsmg.ac.id/prosiding/index.php/feb /issue/view/2/showToc), diakses 29 Maret 2018.
Wahyuni, Tri, Endang Ernawati, dan Werner R. Murhadi. Faktor-Faktor yang Memengaruhi Nilai Perusahaan di Sektor Property, Real Estate \& Building Construction yang Terdaftar di BEI Periode 2008-2012. Calyptra: Jurnal Ilmiah Mahasiswa Universitas Surabaya Vol.2 No.1 (2013). (Online), (journal.ubaya.ac.id/index.php/jimus/article/ view/380), diakses 14 April 2018.

Winata, Fenny. Pengaruh Corporate Governance terhadap Tax Avoidance pada Perusahaan yang Terdaftar di Bursa Efek Indonesia Tahun 2013. Tax \& Accounting Review, Vol. $4 \quad$ No. 1, 2014. (Online), (neliti.com/publications/157323/pengaruhcorporate-governance-terhadap-taxavoidance-pada-perusahaan-yang-terdaf), diakses 24 Maret 2018.

Wulandari, May dan Dovi Septiari. Effective Tax Rate: Efek dari Corporate Governance. Jurnal Akuntansi, Ekonomi dan Manajemen Bisnis 2015 Vol. 3(2) 177-183 ISSN: 23377887.

(Online), (jurnal.polibatam.ac.id/index.php/JAEMB/ar ticle/view/174), diakses 20 Maret 2018.

Yunitasari, Dwimayanti. Pengaruh Kepemilikan Institusional, Kepemilikan Manajerial, dan Agency Cost terhadap Kebijakan Utang pada Sektor Otomotif yang Listing di Bursa Efek Indonesia Periode 2008-2012. Skripsi tidak diterbitkan. Universitas Widyatama. Bandung. (Online), (repository.widyatama.ac.id/xmlui/handle/12 3456789/4625), diakses 5 April 2018. 